\title{
SEASONAL (KHARIF, RABI AND ZAID) PRECIPITATION, POTENTIAL EVAPOTRANSPIRATION AND ARIDITY INDEX WITH RESPECT TO VARIOUS AGRO ECOLOGICAL ZONES OF INDIA
}

\author{
Laxmi GOPARAJU \\ goparajulaxmi@yahoo.com \\ Firoz AHMAD \\ adfiroz@yahoo.com \\ VINDHYAN ECOLOGY AND NATURAL HISTORY FOUNDATION, MIRZAPUR, INDIA
}

\begin{abstract}
Climate change has very significant impact on livelihoods and food security. The geospatial technology provides a better understanding of various themes related to climate change. This study examined the seasonal (kharif, rabi and zaid) long term (1970-2000) monthly climatic parameters such as precipitation, potential evapotranspiration over the country of India. The seasonal Aridity Index was computed and analyzed with respect to various agro-ecological zones of India. The analysis of long term mean precipitation ( $\mathrm{mm}$ ) during kharif, rabi and zaid season was found to be in the range of (14-7463), (0-914) and (0-1722) respectively. The analyses of the long term mean potential evapotranspiration in all seasons was found notable high in arid/semiarid zones. The Aridity Index during kharif, rabi and zaid seasons was found to be in the range of (0.19-4.27), (0.03-0.73) and (0.01-1.48) respectively. The seasonal Aridity Index in some of the agro-ecological zones of the central India in the arid and semiarid regions was found to be notably low. A concrete plan with synergic approach including integrated watershed management and traditional ecological practices will help to fulfill crop water demand and maintain adequate soil moisture for the present and future crops.
\end{abstract}

\section{KEYWORDS:}

Remote sensing/GIS, precipitation, potential evapotranspiration, aridity index, agro ecological zones, India.

\section{Introduction}

Climate change and associated risk have significant direct/indirect impact on crop production and food security
(Reynolds et al. 2018) and a big challenge for the scientists/researchers/policymakers. The geospatial technology and recent free online weather data sets provide great scope 
which offer tangible solutions in term of resilience to farmers/cultivators (Jimenez \& Ramirez-Villegas, 2018). The seasonal/ monthly precipitation patterns in India were studied by several researchers (Mooley \& Parthasarathy, 1983, 1984; Guhathakurta \& Rajeevan, 2008) and their variations impacts the food grain production (Srinivasa Rao et al. 2016). The potential evapotranspiration (PET) is the amount of transfer of water to the atmosphere from land surfaces by evaporation (e.g. from the soil and plant canopy) and via plant transpiration which increases during the summer season due to increase in temperature/solar radiation. The aridity is evaluated by comparing the long-term average of water supply or precipitation to the long-term average of climatic water demand (known as potential evapotranspiration) and an indicator of long-term seasonal climatic water deficits (European Commission, 2018).

The agriculture crops and their growths vary significantly due to seasonal soil moisture and aridity (Spinoni et al. 2015; Salem, 1989). The cultivated agriculture crops during these seasons (kharif, rabi and zaid) varies in water need (supply/demand) across regions (Stefan \& Zhao, 2014; Ashaolu \& Iroye, 2018) due to seasonal change in precipitation and potential evapotranspiration. Such evaluation highlights the need of adequate strategies/ planning for the water conservation for seasonal rainfall/precipitation which is found surplus during the monsoon season and can be used for subsequent dry months. Such arrangement can meet the crop soil moisture demand and boost agricultural production significantly (Killeen \& Solorzano, 2008). The aim of this paper is to investigate the seasonal (kharif, rabi and zaid) long term (1970-2000) monthly climatic parameters such as precipitation, potential evapotranspiration over the country of India and examine the aridity index (AI) (UNESCO, 1979) with respect to various agro ecological zones of India in GIS environment for better understanding of climate-resilience practices against the climate-related risk.

\section{Materials and methods}

\subsection{The study area}

The study area includes the entire land area of India (excluding islands). The geoponic practices are quite common among the rural people and support the livelihood/food chain supply to the majority of people of India. The climate stress in term of variation of precipitation, temperature, and drought are quite common these days in India which impact the agriculture, environmental and social sustainability.

\subsection{Data acquisition and processing}

Here we have systematically evaluated the precipitation and potential evapotranspiration data for kharif (June to October), rabi (November to February) and zaid (March to May) seasons which are strong parameters delicately linked to seasonal crop water supply/demand (Zhao $\&$ Siebert, 2015). These data were used to determine the Aridity Index (UNESCO, 1979) in different agro-ecological zones of India which are highly important to boost agriculture/agroforestry production.

Mean monthly

(1970-2000)

precipitation, data was with spatial resolutions of 30 seconds $\left(\sim 1 \mathrm{~km}^{2}\right)$ was downloaded (http://worldclim.org/version2) for every 12 months (Fick and Hijmans, 2017). Similarly, the Mean monthly (19702000) potential evapotranspiration (PET) dataset also have the same spatial resolution of precipitation was also be downloaded (Trabucco \& Zomer, 2019) for 12 months. The potential-evapotranspiration was calculated based on the Penman-Monteith Evapotranspiration equation (Trabucco \& Zomer, 2019).

The monthly data sets such as precipitation and potential evapotranspiration were arranged based on kharif, rabi and zaid season in GIS domain using ARC/GIS software (Version 10.1). The sub-module such as map algebra/zonal of Spatial 
Analyst toolsets were used significantly for making it seasonal clusters. The vector files of agro-ecosystem of India (Bandyopadhyay et al., 2009) were brought in the GIS domain (Ahmad et al., 2018). The precipitation and potential evapotranspiration data were brought in vector file. The Aridity Index of kharif, rabi and zaid season were calculated based on the ratio of the mean precipitation value to mean potential evapotranspiration value. The above-mentioned data were analyzed and their spatial pattern was examined with GIS queries which give a better understanding of the climate (precipitation, potential evapotranspiration, and AI) distribution pattern of India.

\section{Result and discussion}

The agriculture/forest/agroforestry practices are vital for our life because they satisfy the social, environmental, economic goals and vary significantly in term of distribution pattern with the variation in topography/temperature/precipitation pattern. Agro-ecological zones of India are steered by inter-related geographic factors such as climate/soil/physiographic environment which manifested in term of the diversity of agriculture/forest/trees/livestock dominance
(Balasubramanian 2013). The agroecological zones of India used here are delineated based on the growing period as integrated criteria of effective rainfall, soil groups, with twenty major agro-ecological zones (Bandyopadhyay et al. 2009). These various agro-ecological zones and their seasonal (kharif, rabi and zaid) changes of precipitation, potential evaporation and aridity index are important for farmers/cultivators for better understanding of existing/future water requirements for crops in achieving sustainability due to climate change impact.

\subsection{Precipitation pattern analysis}

The various crops/trees activity practiced by farmers/cultivators of India is delicately connected to seasonal precipitation distribution pattern. Their variation impacts the crops due to water supply/demand which is essential for their metabolic activity and growth. The long term (19702000) seasonal (kharif, rabi and zaid) precipitation maps produced were given in Figure no. 1-3 which shows huge spatial variation. The agro-ecosystem zones wise mean precipitation and potential evaporation were also computed which are given in Table no. 1.

Table no. 1

The long term (1970-2000) mean of precipitation and potential evapotranspiration in various agro ecological zones of India

\begin{tabular}{|l|c|c|c|c|c|c|}
\hline \multirow{2}{*}{$\begin{array}{c}\text { Agro-ecological } \\
\text { region of India }\end{array}$} & $\begin{array}{c}\text { Kean } \\
\text { precipitation } \\
(\mathrm{mm})\end{array}$ & $\begin{array}{c}\text { Mean } \\
\text { potential } \\
\text { evaporation } \\
(\mathrm{mm})\end{array}$ & $\begin{array}{c}\text { Mean } \\
\text { precipitation } \\
(\mathrm{mm})\end{array}$ & $\begin{array}{c}\text { Mean } \\
\text { potential } \\
\text { evaporation } \\
(\mathrm{mm})\end{array}$ & $\begin{array}{c}\text { Mean } \\
\text { precipitation } \\
(\mathrm{mm})\end{array}$ & $\begin{array}{c}\text { Mean } \\
\text { potential } \\
\text { evaporation } \\
(\mathrm{mm})\end{array}$ \\
\hline $\begin{array}{l}\text { 1. Western Himalayas } \\
\text { (Cold region) }\end{array}$ & 114.132 & 599.136 & 28.9338 & 155.209 & 40.2536 & 219.52 \\
\hline $\begin{array}{l}\text { 2.Western Plain and } \\
\text { Kachchh Peninsula }\end{array}$ & 334.797 & 1052.76 & 13.699 & 542.574 & 13.4297 & 762.983 \\
\hline $\begin{array}{l}\text { 3. Deccan Plateau } \\
\text { (Hot Arid) }\end{array}$ & 459.707 & 804.53 & 38.5279 & 631.455 & 94.1505 & 699.554 \\
\hline $\begin{array}{l}\text { 4. Northern Plain and } \\
\text { Central Highlands }\end{array}$ & 708.651 & 897.121 & 31.8918 & 483.791 & 18.91 & 735.388 \\
\hline $\begin{array}{l}\text { 5. Central Malwa } \\
\text { Highlands and } \\
\text { Kathiawar Peninsula }\end{array}$ & 845.276 & 882.471 & 16.5426 & 614.128 & 10.0021 & 806.496 \\
\hline 6. Deccan Plateau & 820.005 & 823.031 & 33.4526 & 630.168 & 55.3653 & 772.58 \\
\hline
\end{tabular}




\begin{tabular}{|l|c|c|c|c|c|c|}
\hline \multicolumn{1}{|c|}{$\begin{array}{c}\text { Agro-ecological } \\
\text { region of India }\end{array}$} & $\begin{array}{c}\text { Kean } \\
\text { precipitation } \\
\text { (mm) }\end{array}$ & $\begin{array}{c}\text { Mean } \\
\text { potential } \\
\text { evaporation } \\
\text { (mm) }\end{array}$ & $\begin{array}{c}\text { Mean } \\
\text { precipitation } \\
\text { (mm) }\end{array}$ & $\begin{array}{c}\text { Mean } \\
\text { potential } \\
\text { evaporation } \\
\text { (mm) }\end{array}$ & $\begin{array}{c}\text { Mean } \\
\text { precipitation } \\
\text { (mm) }\end{array}$ & $\begin{array}{c}\text { Mean } \\
\text { potential } \\
\text { evaporation } \\
\text { (mm) }\end{array}$ \\
\hline $\begin{array}{l}\text { (Hot semi-arid region) } \\
\text { 7. Deccan (Telengana) } \\
\text { Plateau and Eastern } \\
\text { Ghats }\end{array}$ & 697.727 & 851.495 & 56.0726 & 586.399 & 65.0886 & 720.676 \\
\hline $\begin{array}{l}\text { 8. Eastern Ghats (Tamil } \\
\text { Nadu Uplands) and } \\
\text { Deccan Plateau } \\
\text { (Karnataka) }\end{array}$ & 497.255 & 837.612 & 188.255 & 572.174 & 131.495 & 625.84 \\
\hline 9. Northern Plain & 922.842 & 800.803 & 56.7331 & 425.608 & 37.2198 & 682.776 \\
\hline $\begin{array}{l}\text { 10. Central Highlands } \\
\text { (Malwas and } \\
\text { Budelkhand) }\end{array}$ & 1093.29 & 835.155 & 37.5005 & 546.937 & 18.946 & 795.941 \\
\hline $\begin{array}{l}\text { 11. Deccan Plateau } \\
\text { and Central Highlands } \\
\text { (Budelkhand) }\end{array}$ & 1104.86 & 780.706 & 45.1777 & 512.374 & 33.6588 & 751.201 \\
\hline $\begin{array}{l}\text { 12. Eastern Plateau } \\
\text { (Chhattisgarh) }\end{array}$ & 1203.92 & 726.774 & 40.1126 & 495.65 & 50.8245 & 728.511 \\
\hline $\begin{array}{l}\text { 13. Eastern } \\
\text { (Chotanagpur) Plateau } \\
\text { and Eastern Ghats }\end{array}$ & 1250.64 & 720.35 & 48.3215 & 511.061 & 100.49 & 687.941 \\
\hline 14. Eastern Plain & 1109.43 & 740.328 & 36.8407 & 427.523 & 64.9269 & 647.474 \\
\hline 15. Western Himalayas & 670.257 & 690.232 & 185.165 & 253.86 & 179.245 & 385.11 \\
\hline $\begin{array}{l}\text { 16. Bengal and Assam } \\
\text { plains }\end{array}$ & 1698.69 & 643.4559 & 85.1064 & 427.8565 & 566.863 & 495.651 \\
\hline 17. Eastern Himalayas & 1360.03 & 547.1575 & 66.7246 & 325.1055 & 307.885 & 362.839 \\
\hline $\begin{array}{l}\text { 18. North Eastern Hills } \\
\text { (Purvanchal) }\end{array}$ & 1980.44 & 582.778 & 90.2862 & 397.886 & 504.714 & 450.916 \\
\hline $\begin{array}{l}\text { 19. Eastern Coastal } \\
\text { Plain }\end{array}$ & 910.384 & 816.267 & 199.854 & 540.917 & 93.4074 & 612.796 \\
\hline $\begin{array}{l}\text { 20. Western Ghats and } \\
\text { Coastal Plain }\end{array}$ & 2792.01 & 653.736 & 113.42 & 605.255 & 201.637 & 582.013 \\
\hline
\end{tabular}

The analysis of long term mean precipitation $(\mathrm{mm})$ during kharif, rabi and zaid season in India was found to be in the range of (14-7463), (0-914) and (0-1722) respectively. The evaluation of long term mean precipitation with respect of various agro-ecological zone during kharif season was found highest $(2792 \mathrm{~mm})$ in the categories of "Western Ghats and Coastal Plain" followed by "North Eastern Hills (Purvanchal): 1980 mm", "Bengal and Assam plains: $1699 \mathrm{~mm}$ " (Table no. 1). The lowest was found in category of "Western Himalayas (Cold region): $114 \mathrm{~mm}$ ) during the same base season. Similarly, during the rabi season the mean precipitation $(\mathrm{mm})$ were found significantly high in the categories of "Eastern Coastal Plain: 200 mm", "Eastern Ghats (Tamil Nadu Uplands) and Deccan Plateau (Karnataka):188 mm" and "Western Himalayas: $185 \mathrm{~mm}$ ". During the zaid season the mean precipitation $(\mathrm{mm})$ were found significantly high in the categories of "Bengal and Assam plains: $567 \mathrm{~mm}$ ", "North Eastern Hills (Purvanchal): $505 \mathrm{~mm}$ " and "Eastern Himalayas: $308 \mathrm{~mm}$ ". A similar observation was found by Rajeevan et al. 2012 and Birthal et al. 2014. 


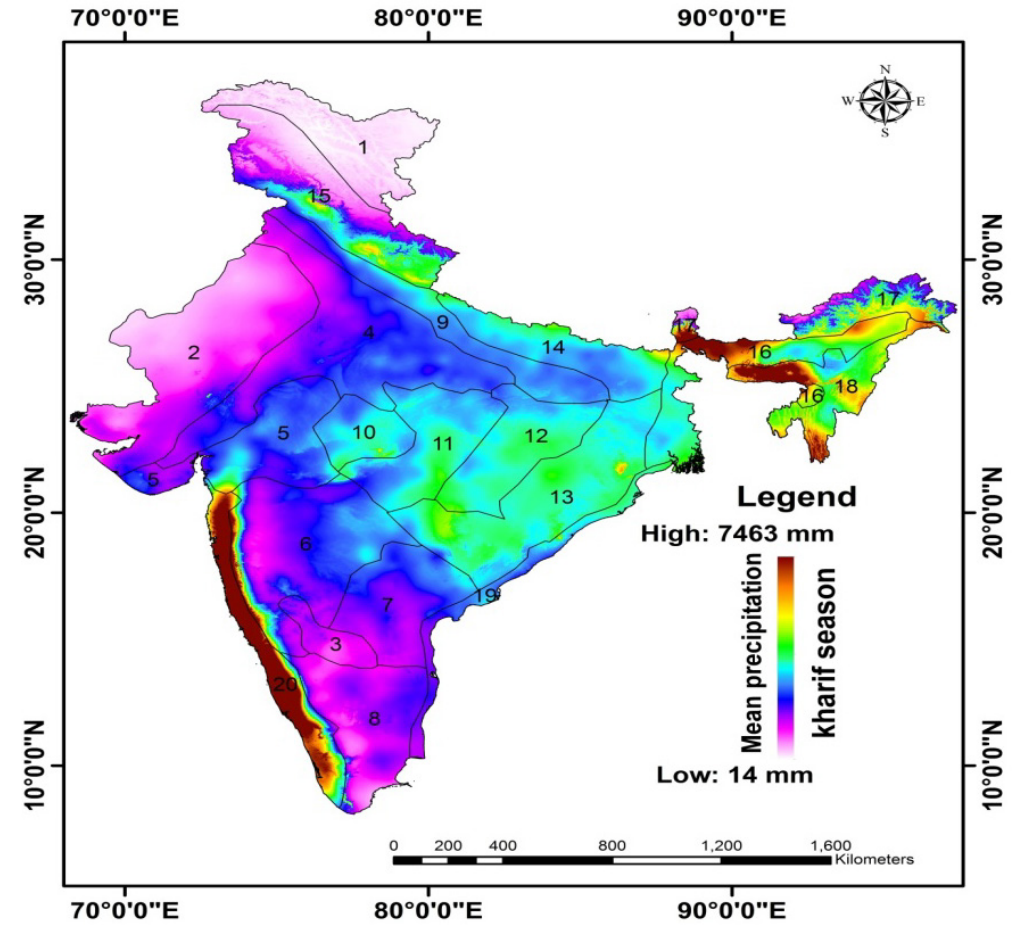

Figure no. 1. Mean long-term (1970-2000) kharif season precipitation overlaid by agro ecological zone of India

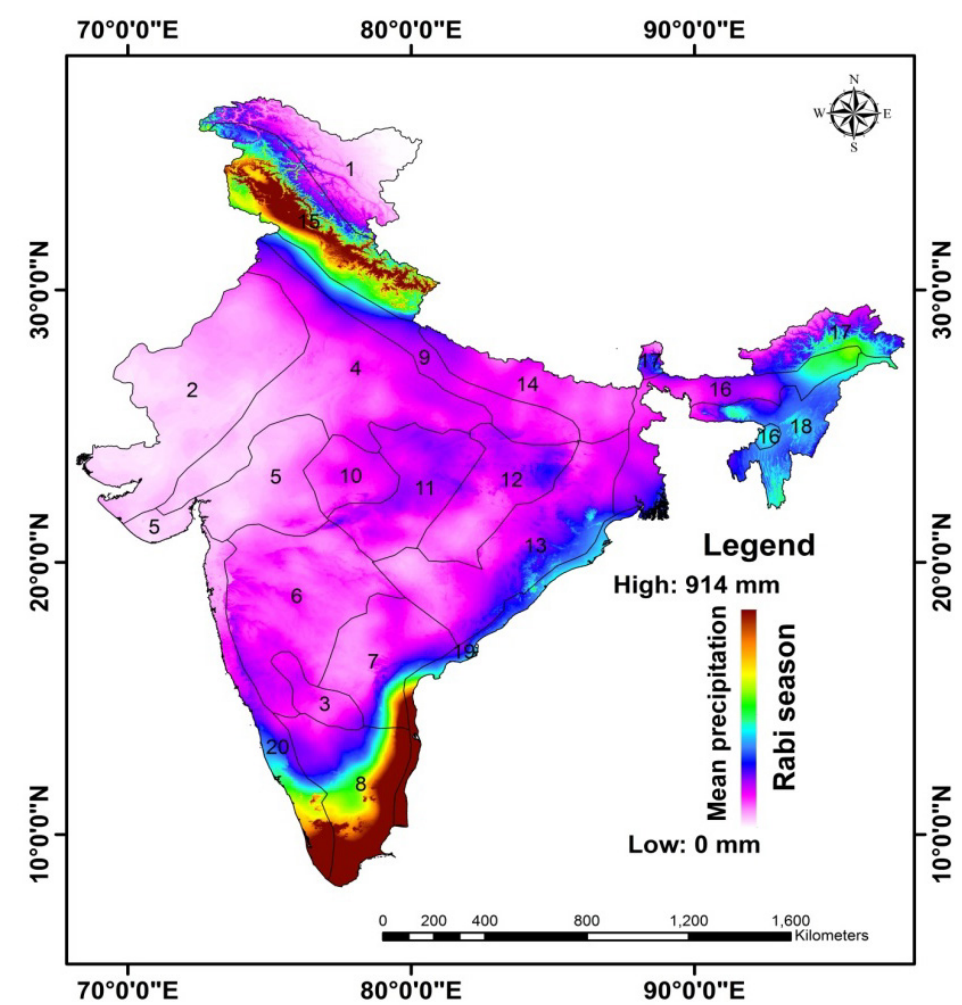

Figure no. 2. Mean long-term (1970-2000) rabi season precipitation overlaid by agro ecological zone of India 


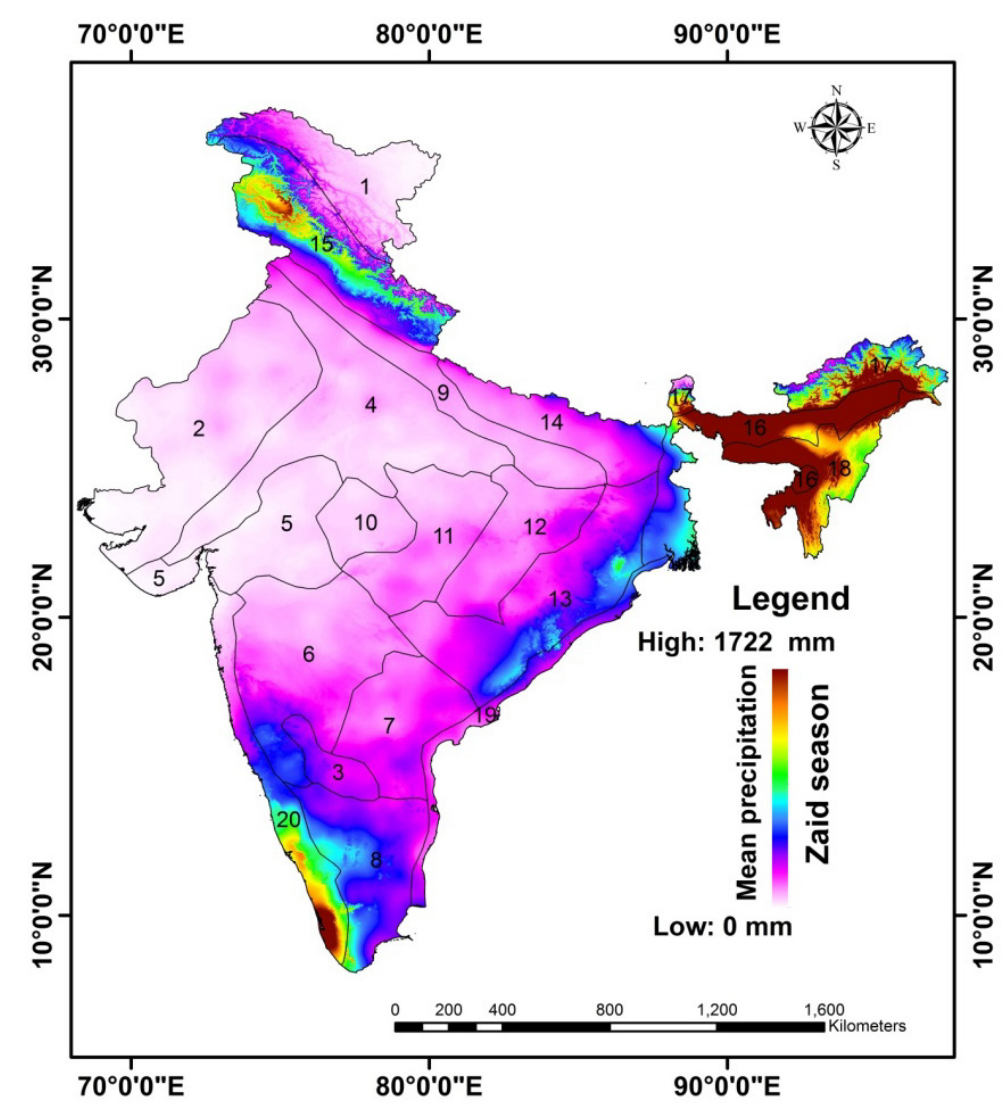

Figure no. 3. Mean long-term (1970-2000) zaid season precipitation overlaid by agro ecological zone of India

\subsection{Potential evapotranspiration pattern analysis}

The seasonal potential evapotranspiration and their variability play a crucial role which influence the hydrological arrangement thus impact the vegetation health including seasonal crops water demand (Liu et al., 2015). The evaluations significantly help in various applications including irrigation management and in climate change impacts (Lang et al., 2017). The long-term (1970-2000) PET maps were generated for kharif, rabi and zaid seasons of India were given in Figure 4-6. The longterm PET pattern in all three seasons are found more pronounce and significantly high in various agro eco region of arid and semi-arid regions of India. These regions are significantly high climate severity/ limitations (Tewari et al., 2014). The analysis of long term mean PET (mm) during kharif, rabi and zaid season in India are found to be in the range of (34-1291), (11-742) and (6-903) respectively. The investigation of long term mean PET with respect of various agro-ecological zone during kharif season is found to be highest $(1053 \mathrm{~mm})$ in the categories of "Western Plain and Kachchh Peninsula" followed by "Northern Plain and Central Highlands: 897 mm", "Deccan (Telengana) Plateau and Eastern Ghats: 852 mm" (Table no. 1). The analysis revealed all arid zones shows high mean PET in all seasons whereas the agro ecological zone category "Deccan Plateau (Hot Arid)" is the only category retain the highest mean PET $>600 \mathrm{~mm}$ in all three seasons (Table no. 1). 


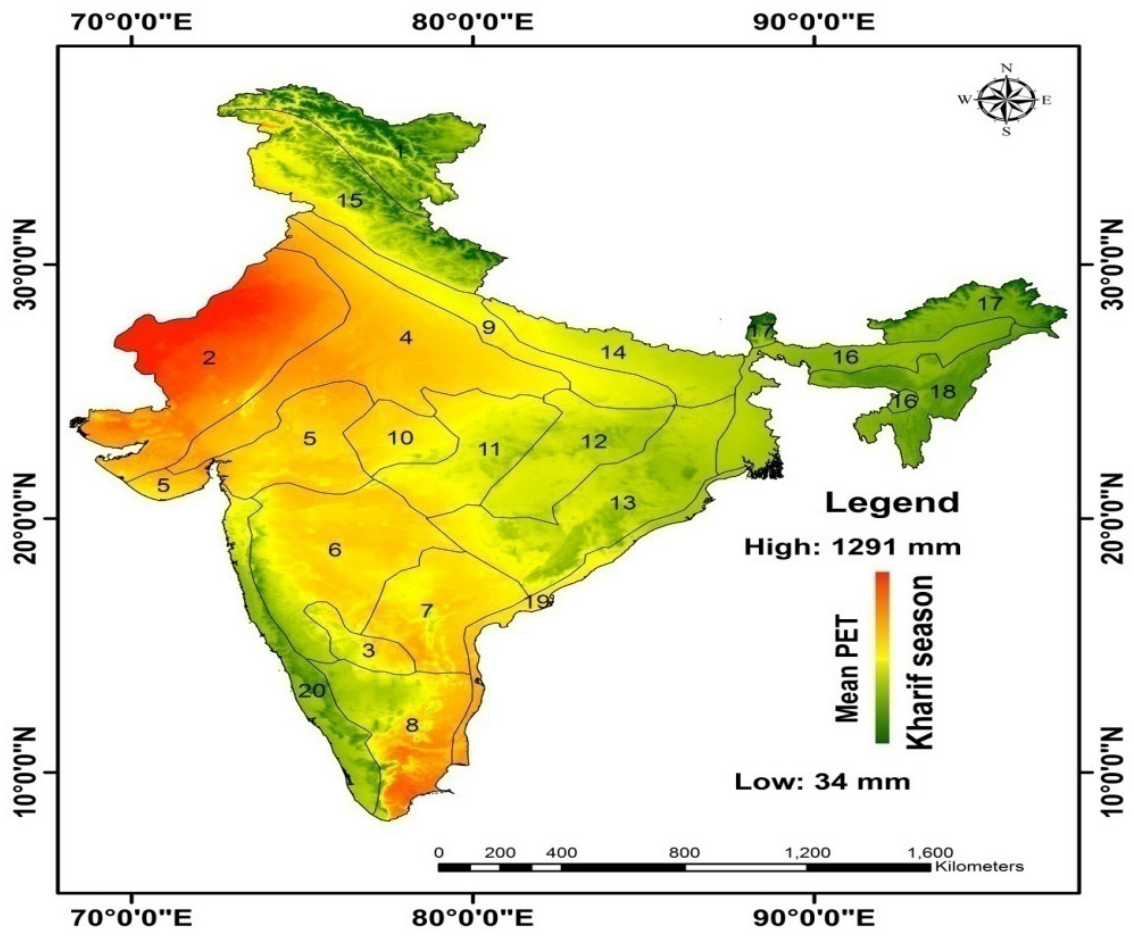

Figure no. 4. Mean long-term (1970-2000) kharif season potential evapotranspiration overlaid by agro ecological zone of India

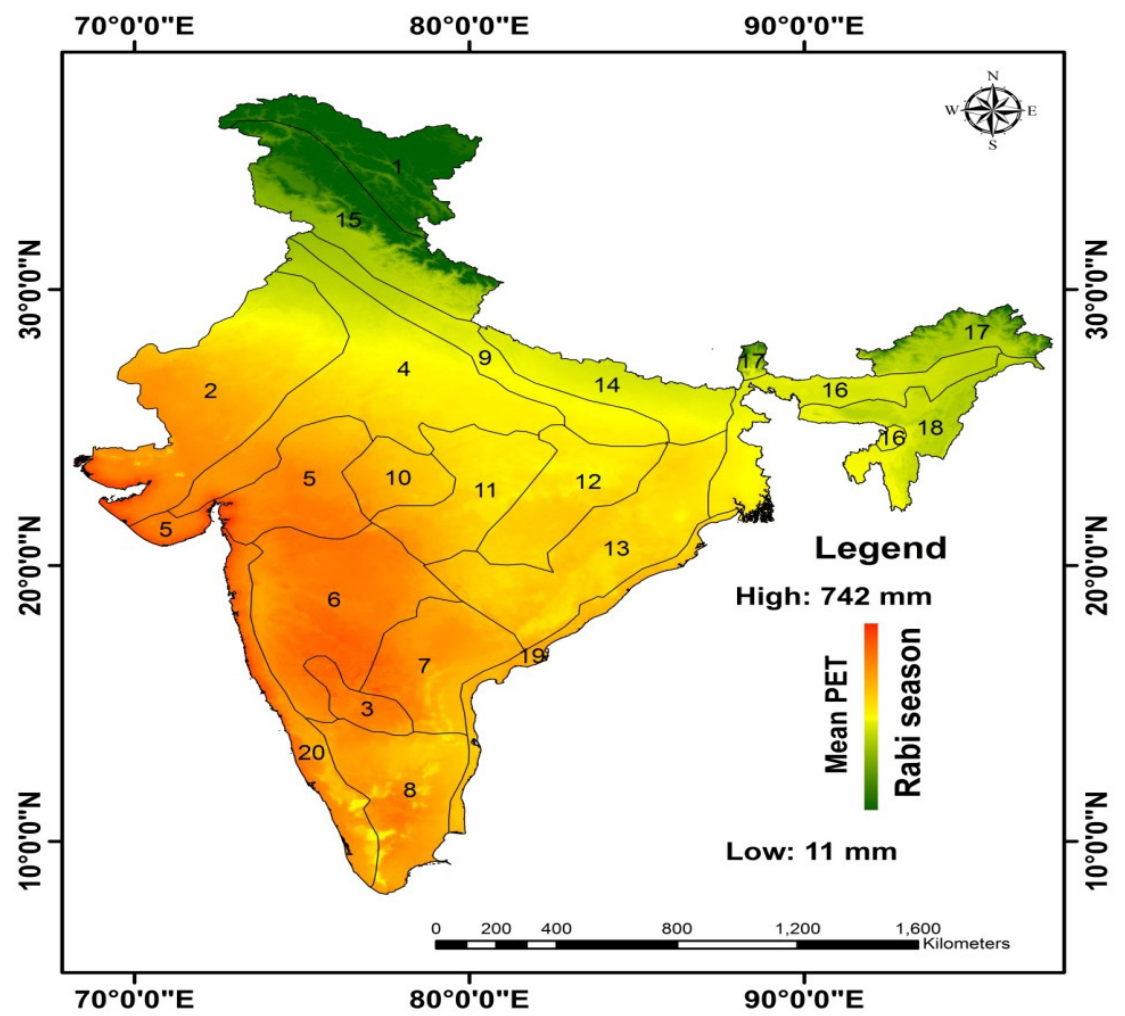

Figure no. 5. Mean long-term (1970-2000) rabi season potential evapotranspiration overlaid by agro ecological zone of India 


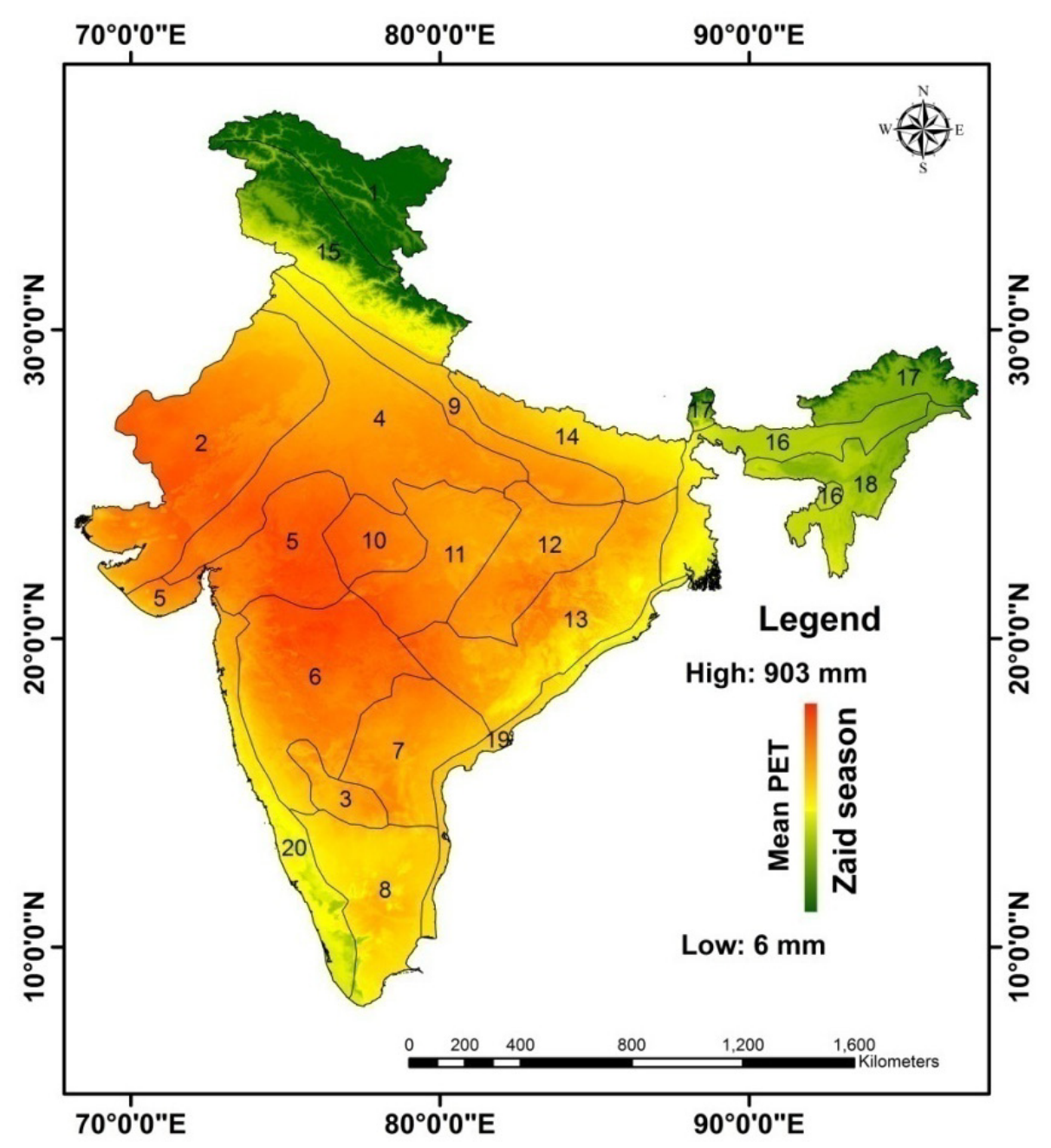

Figure no. 6. Mean long-term (1970-2000) zaid season potential evapotranspiration overlaid by agro ecological zone of India

\subsection{Aridity index pattern analysis}

Aridity indexes are quantitative measure of the degree of water shortage and are very usually related to distributions of natural vegetation and crops (Stephen, 2005). In this computation, we have used the aridity index formula (ratio of precipitation to potential evapotranspiration) (UNESCO, 1979) which is globally documented (Maliva \& Missimer, 2012; Trabucco \& Zomer, 2019). The AI for the seasons (kharif, rabi and zaid) were analyzed with respect to 20 agro ecological zones of India are given in Figure no. 7-9. The two zones categories 16 and 17 are found in two geographical locations were analyzed separately (for AI). In the present study, we have addressed one the critical research gaps such as seasonal evaluations of AI with respect to agro ecological zones of India. These analyses significantly help in geoponic sustainability as an adaptation to climate change (Zomer et al., 2007, 2008). 


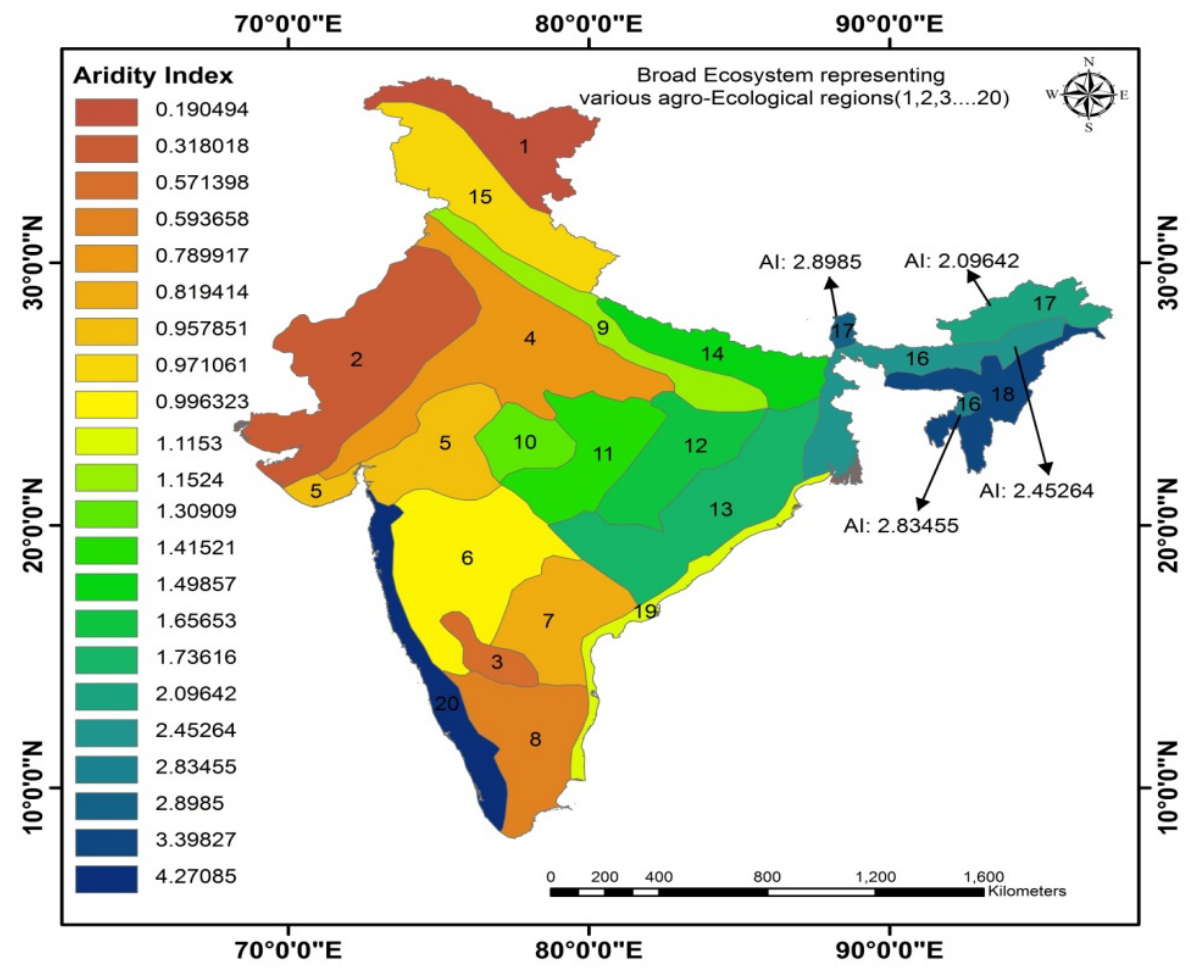

Figure no. 7. Aridity Index of various agro ecological zones in kharif season of India

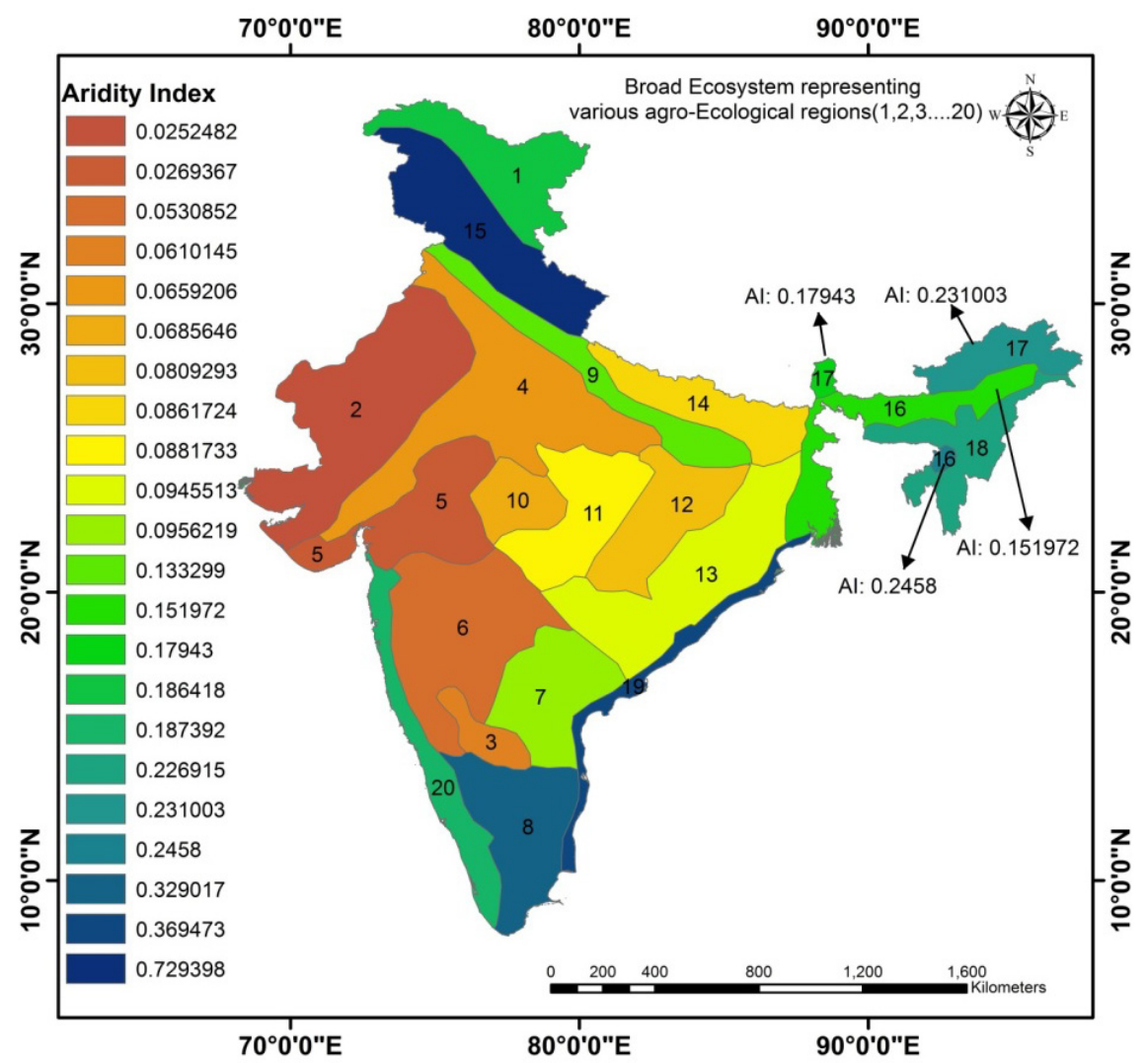

Figure no. 8. Aridity Index of various agro ecological zones in rabi season of India 


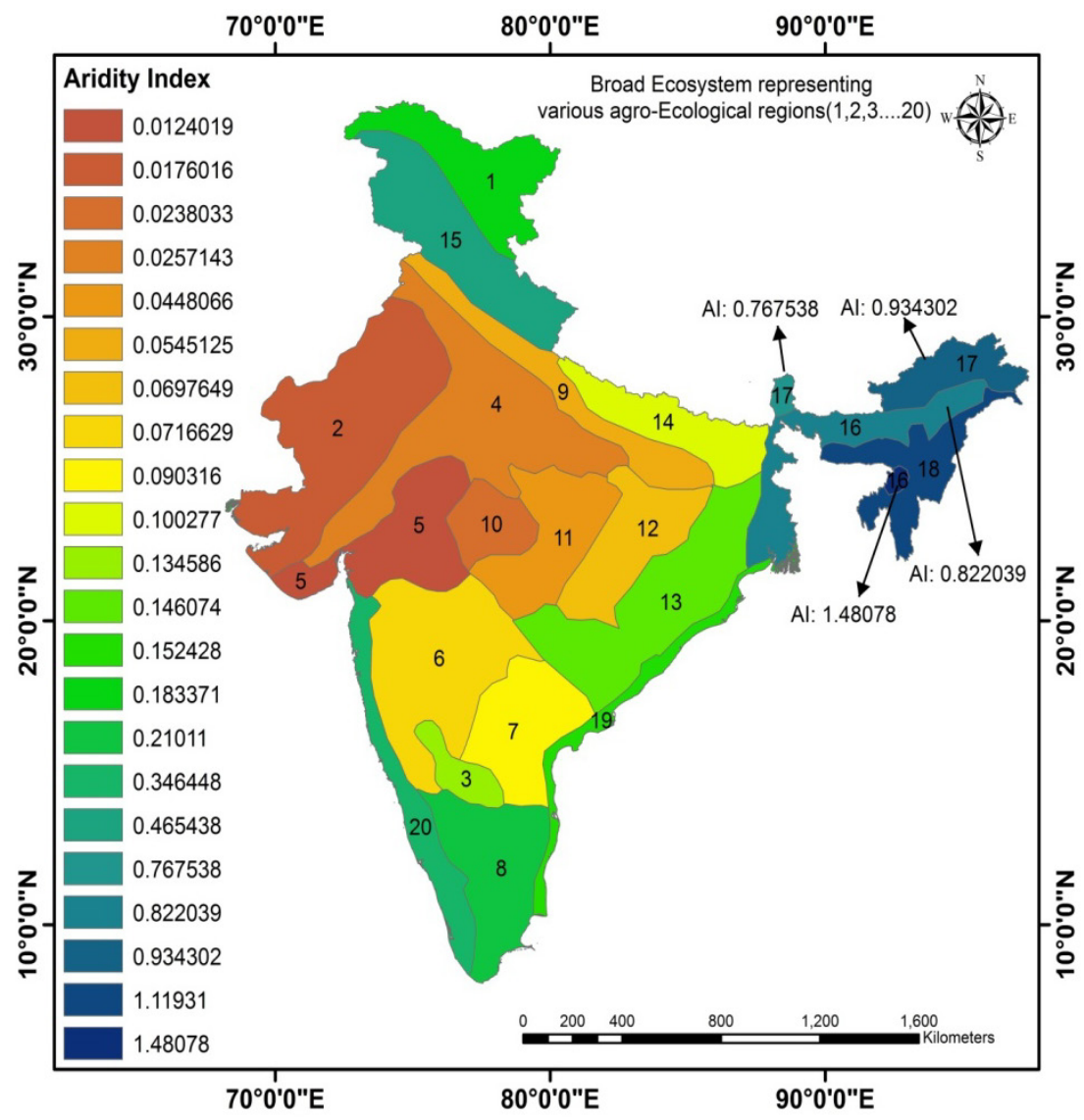

Figure no. 9. Aridity Index of various agro ecological zones in zaid season of India

The higher values AI manifest more humid condition whereas the lowest value for more xeric condition (Zomer et al., 2008). The AI during kharif, rabi and zaid seasons in India are found to be in the range of (0.19-4.27), (0.03-0.73) and (0.01-1.48) respectively (Figure no. 7-9). The AI greater than 1 during kharif season is found in 11 agro ecological regions (Figure no. 7). These zones during the kharif season have significantly high soil moisture and largely utilized for rice cultivation. The AI during rabi season are found significantly low in major of the agro ecological zones except the categories "Western Himalayas", "Eastern Coastal Plain" and "Eastern Ghats (Tamil Nadu Uplands) and Deccan Plateau (Karnataka)". The majority of these areas where the AI is found significantly high are due to adequate precipitation during returning northeast monsoon (Rajeevan et al., 2012). In the category "Western
Himalayas" the AI during the rabi season was found to be highest because of the significantly low potential evapotranspiration specially due to low temperature occurrence in hilly/mountain tracks of Himalayas (Figure no. 8 and Table no. 1). The majority of the central Indian agro ecological zones showed low AI during the zaid season due to high stress of weather severity in terms of high temperature, potential evapotranspiration (Figure no. 6) and low precipitation (Figure no. 3). The rise of mean annual temperature was found to be very significant these days which continuously magnifies the drying phenomenon (Ramachandran et al., 2015). Such phenomenon increases the seasonal PET and decrease the aridity index significantly which leads to more water crop demand. It was also observed that several agro ecological zones receive adequate precipitation during the kharif 
season (Figure no. 1). These zones can be utilized for water conservation practices at watershed level which will help significantly to support crop water demand and maintain adequate soil moisture. Such action will boost the agriculture crop production in present climate change scenario (Wani et al., 2003). The seasonal AI in some of the agro ecosystem zones of the central India such as the states Andhra Pradesh, Telangana, Karnataka and Madhya Pradesh in the arid and semiarid regions were found notably low and well known for farmer's suicide hot spot (Carleton, 2017). These areas are also suffering from poverty (Lewis, 2013). There is a need develop a concrete plan with synergic approach which includes integrated watershed management strategies with traditional ecological practices for achieving long-term sustainable goals (Goparaju \& Ahmad, 2019; James et al., 2018).

\section{Conclusion}

In the present study, we have used long term (1970-2000) datasets such as seasonal precipitation, potential evapotranspiration of India. Furthermore, we have compiled the seasonal AI to address one of the critical research gaps with respect to various agro ecological zones of India. In our study, we found several agro ecological zones of India which receive adequate precipitation during kharif season and manifested with low aridity index in the rabi and the zaid season. These agro ecological zones with low AI need to be addressed by synergic approach/strategies of rainwater conservation at the watershed level with suitable technologies (Sivanappan). Such measures/approach with integrated watershed management will enhance the soil moisture to support adequately various agriculture/agroforestry/horticulture crops at regional level (Ahmad \& Goparaju, 2017). These types of practices when integrated with various ancillary data sets of various agro ecosystem zones will improve the farmers/cultivators socio economic condition and support significantly as an adaptation of climate change. Furthermore, the evaluation of present study highlights the need of synergic approaches/strategies especially in arid and semi-arid regions to mitigate the climate change impact on farmer's suicidal hotspot as long term goal to obtain sustainability in food security, enhancing the livelihood and magnifying the farm household (Goparaju \& Ahmad, 2019). The potentialities of geospatial technology have the enormous capability and will support significantly when integrated with in situ ancillary datasets to address the cultivator's issues.

\section{Acknowledgements}

The authors are grateful to the World Clim-Global Climate Data, CGIAR Geospatial Community of Practice/Consortium for Spatial Information (CGIAR-CSI) and, DIVA GIS for providing free download of various dataset used in the analysis.

\section{REFERENCES}

Ahmad, F., \& Goparaju, L. (2017). Land evaluation in terms of agroforestry suitability, an approach to improve livelihood and reduce poverty: a FAO based methodology a geospatial solution: a case study of Palamu district, Jharkhand, India. Ecological Questions, Vol. 25, 67-84, available at: https://doi.org/10.12775/EQ.2017.006.

Ahmad, F., Uddin, M. M., \& Goparaju, L. (2018). Agroforestry suitability mapping of India: geospatial approach based on FAO guidelines. Agroforest Systems, available at: https://doi.org/10.1007/s10457-018-0233-7. 
Ashaolu, E. D., \& Iroye, K. A. (2018). Rainfall and potential evapotranspiration patterns and their effects on climatic water balance in the Western Lithoral Hydrological Zone of Nigeria. Ruhuna Journal of Science, Vol. 9, Issue 2, 92-116, available at: http://doi.org/10.4038/rjs.v9i2.45.

Balasubramanian, A. (2013). Agro-Ecological Zones of India, available at: https:// www.researchgate.net/publication/314206350_AGROECOLOGICAL_ZONES_OF_INDIA.

Bandyopadhyay, A., Bhadra, A., Raghuwanshi, N.S., \& Singh, R. (2009). Temporal trends in estimates of reference evapotranspiration over India. Journal of Hydrologic Engineering, Vol. 14, Issue 5, 508-515.

Birthal, P., Tajuddin, K. M., Negi, D., \& Agarwal, S. (2014). Impact of Climate Change on Yields of Major Food Crops in India: Implications for Food Security. Agricultural Economics Research Review, Vol. 27, 145, DOI:10.5958/0974-0279.2014.00019.6.

Carleton,T. A. (2017). Crop-damaging temperatures increase suicide rates in India. Proceedings of the National Academy of Sciences of the United States of America, Vol. 114, Issue 33, 8746-8751, available at: https://doi.org/10.1073/pnas.1701354114.

European Commission. (2018). Patterns of Aridity. Joint Research Centre World Atlas of Desertification, available at: https://wad.jrc.ec.europa.eu/patternsaridity.

Fick, S. E., \& Hijmans, R. J. (2017). Worldclim 2: New 1-km spatial resolution climate surfaces for global land areas. International Journal of Climatology, Vol. 37, Issue 12, 4302-4315, https://doi.org/10.1002/joc.5086.

Goparaju, L., \& Ahmad, F. (2019). Analyzing the risk related to Climate Change attributes and their impact, a step towards Climate-Smart Village (CSV): a geospatial approach to bring geoponics sustainability in India. Spatial Information Research, available at: https://doi.org/10.1007/s41324-019-00258-0.

Guhathakurta, P., \& Rajeevan, M. (2008). Trends in the rainfall pattern over India. International Journal of Climatology, Vol. 28, Issue 11, 1453-1469.

James, A. J., Bahadur, A. V., \& Verma, S. (2018). Climate Resilient Water Management: An operational framework from South Asia. Action on Climate Today Learning Paper, Acclimatise and Oxford Policy Management.

Jimenez, D., \& Ramirez-Villegas, J. (2018). Unlocking Big Data's Potential to Strengthen Farmers' Resilience: The Platform for Big Data in Agriculture. In: Ospina, A. V. Big Data for resilience storybook: Experiences integrating Big Data into resilience programming (pp. 97-108). Winnipeg: International Institute for Sustainable Development.

Killeen, T. J., \& Solorzano, L. A. (2008). Conservation strategies to mitigate impacts from climate change in Amazonia. Philosophical Transactions of the Royal Society of London. Series B Biological Sciences, Vol. 363, Issue 1498, 1881-1888. doi: 10.1098/rstb.2007.0018.

Lang, D., Zheng, J., Shi, J., Liao, F., Ma, X., Wang, W., Chen, X., \& Zhang, M. (2017). A comparative study of potential evapotranspiration estimation by eight methods with FAO Penman-Monteith method in southwestern China. Water, Vol. 9, Issue 10, 734, DOI: $10.3390 /$ w9100734.

Lewis, M. W. (2013). Remapping Poverty in India. GeoCurrents, available at: http://www.geocurrents.info/geonotes/remapping-poverty-in-india, accessed on 22 January 2019.

Liu, Y., Ren, L., Yang, X., Ma, M., Yuan, F., \& Jiang, S. (2015). Effects of precipitation and potential evaporation on actual evapotranspiration over the Laohahe basin, northern China. Proceedings of IAHS, Vol. 371, 173-179, available at: https://doi.org/10.5194/piahs-371-173-2015. 
Maliva, R., \& Missimer, T. (2012). Arid Lands Water Evaluation and Management. Environmental Science and Engineering, DOI: 10.1007/978-3-642-29104-3_2.

Mooley, D. A., \& Parthasarathy, B. (1983). Variability of the Indian summer monsoon and tropical circulation features. Monthly Weather Review, Vol. 111, Issue 5, 967-968.

Mooley, D. A., \& Parthasarathy, B. (1984). Fluctuations in All-India summer monsoon rainfall during 1871-1978. Climatic Change, Vol. 6, Issue 3: 287-301, available at: https://doi.org/10.1007/BF00142477.

Rajeevan, M., Unnikrishnan, C. K, Jyoti, B., Niranjan, K., \& Sreekala, P. (2012). Northeast Monsoon over India: Variability and Prediction. Meteorological Applications. Vol. 19 (2), 226 - 236. DOI: 10.1002/met.1322.

Ramachandran, A., Praveen, D., Jaganathan, R., \& Palanivelu, K. (2015). Projected and observed aridity and climate change in the east coast of south India under RCP 4.5. The Scientific World Journal, Vol. 2015, 11, available at: https://doi.org/ $\underline{10.1155 / 2015 / 169761 .}$.

Reynolds, M., Kropff, M., Crossa, J., Koo, J., Kruseman, G., Molero Milan, A., Rutkoski, J., Schulthess, U., Balwinder-Singh, Sonder, K., Tonnang, H., \& Vadez, V. (2018). Role of Modelling in International Crop Research: Overview and Some Case Studies. Agronomy, Vol. 8 (12), 291, available at: https:// doi.org/ 10.3390/ agronomy8120291.

Salem, B. B. (1989). Arid Zone Forestry: A Guide for Field Technicians (Fao Conservation Guide, 20). Rome, Italy: Food \& Agriculture Org, available at: http:// www.fao.org/ docrep/t0122e/ t0122e03.htm.

Sivanappan, R. K., Technologies for water harvesting and soil moisture conservation in small watersheds for small-scale irrigation, India, available at: http:// www.fao.org/3/ w7314e/ w7314e0q.htm\#TopOfPage.

Spinoni, J., Vogt, J., \& Barbosa, P. (2015). European degree-day climatologies and trends for the period 1951-2011. International Journal of Climatology, Vol. 35, Issue 1, 25-36, available at: https://doi.org/10.1002/joc.3959.

Srinivasa Rao, Ch., Gopinath, K.A., Prasad, J.V.N.S., Kumar, P., \& Singh, A.K. (2016). Climate resilient villages for sustainable food security in tropical India: concept, process, technologies, institutions, and impact. Advances in Agronomy, Vol. 140, 101-214, available at: http://dx.doi.org/ 10.1016/bs.agron.2016.06.003.

Stefan, S., \& Zhao, G. (2014). Mapping of rainfed and irrigated agriculture in Indiadata inventory and documentation. Technical report, GEOSHARE pilot - Crop Science Bonn, available at: https://mygeohub.org/publications/11/serve/1/17.

Stephen, J. (2005). Aridity Indexes. In: Oliver, J. E. (eds). Encyclopedia of World Climatology. Encyclopedia of Earth Sciences Series. Dordrecht: Springer, available at: https://doi.org/10.1007/1-4020-3266-8 17.

Tewari, J. C., Ram, M., Roy, M., \& Dagar, J. C. (2014). Livelihood Improvements and Climate Change Adaptations Through Agroforestry in Hot Arid Environments. In: Dagar, J., Singh, A., Arunachalam, A. (eds) Agroforestry Systems in India: Livelihood Security \& Ecosystem Services. Advances in Agroforestry, Vol. 10, New Delhi: Springer, available at: https://doi.org/10.1007/978-81-322-1662-9 6.

Trabucco, A., \& Zomer, R. (2019). Global Aridity Index and Potential Evapotranspiration Climate Database v2. CGIAR Consortium for Spatial Information (CGIAR-CSI), available at: https://cgiarcsi.community/2019/01/24/global-aridity-index-andpotential-evapotranspiration-climate-database-v2/.

United Nations Educational, Scientific and Cultural Organization (UNESCO). (1979). Map of the World Distribution of Arid Regions: Explanatory Note. Paris, France: UNESCO. 
Wani, S. P., Pathak, P., Sreedevi, T. K., Singh, H. P., \& Singh, P. (2003). Efficient management of rainwater for increased crop productivity and groundwater recharge in Asia. IWMI Books, Reports H032643, Colombo, Sri Lanka: International Water Management Institute.

WorldClim-Global Climate Data (Version 2). (2016). available at: http://worldclim.org/ version2.

Zhao, G., \& Siebert, S. (2015). Season-wise irrigated and rainfed crop areas for India around year 2005. MyGeoHUB. doi: 10.13019/M2CC71

Zomer, R. J., Bossio, D. A., Trabucco, A., Yuanjie, L., Gupta, D. C., \& Singh, V. P. (2007). Trees and Water: Smallholder Agroforestry on Irrigated Lands in Northern India. IWMI Research Report 122, Colombo, Sri Lanka: International Water Management Institute.

Zomer, R. J., Trabucco, A., Bossio, D. A., \& Verchot, L.V. (2008). Climate change mitigation: a spatial analysis of global land suitability for clean development mechanism afforestation and reforestation. Agriculture Ecosystems \& Environment, Vol. 126 (1-2), 67-80, doi: 10.1016/j.agee.2008.01.014. 